\title{
Impacts of COVID-19 Pandemic on Sustainability/Survivability of Micro/Small Sized Businesses in Nigeria
}

\author{
Anthony Wakwe Lawrence ${ }^{1} \&$ Damiete Onyema Lawrence ${ }^{2}$ \\ 1 Chairman and Chief Consultant on Sustainable Development and Management Research, Community \\ Inter-Relations and Conciliation Initiative (CIRCI), Port Harcourt, Nigeria \\ ${ }^{2}$ PhD Student, Rivers State University, Port Harcourt, Nigeria, Business Development officer, CINFORES, Port \\ Harcourt, Nigeria and Research Partner with CIRCI, Nigeria \\ Correspondence: Anthony Wakwe Lawrence, 7 All Saints' Street, UPE Sandfill, Borikiri, Port Harcourt, Nigeria. \\ E-mail: tonylawrence942@gmail.com
}

Received: April 22, 2021

doi:10.5539/ijbm.v16n9p1
Accepted: June 14, 2021

Online Published: July 9, 2021

\begin{abstract}
Coronavirus pandemic (COVID-19) is currently the biggest crisis affecting the world. COVID-19 has claimed the lives of millions and is impacting the economic lives, ways of life and at least psychological health of most people. We used Port Harcourt as area of study to understand if sizes and types of these businesses affect sustainability/survivability in relation to the impact of COVID-19. We administered questionnaires to 568 business owners/mangers of 11 business types of the two sizes (micro and small). The information gathered were analysed using both quantitative and qualitative means and also presented graphically. The micro-sized businesses were more successful in terms of their abilities to continue getting patronage, getting supplies, retaining workers and eventually making profit during the peak of COVID-19 pandemic. Those whose products were considered more essential in relation to lockdown and health circumstances: fruit sellers, online enabled businesses, Point of Sale units (POS), drugs and petroleum product sellers thrived better than others. Considering the subsistent level of existence of these micro and small sized businesses, their major needs are effective provision of credit facilities and availability of other supportive business interventions including provision of palliatives/relief measures during crisis to real business operators and not to 'ghosts' by government and others to sustainably grow their businesses. As population pressure increases, with the attendant rise in unemployment rate, recommendation is made for business entrepreneurial skills to be incorporated into all levels of educational curricula to facilitate greater chance of success for those who choose the business pathway.
\end{abstract}

Keywords: micro-sized, small-sized, Coronavirus-Pandemic, business-size, business-types, business-profitability, business-management-skills

\section{Introduction}

One of the major challenges facing micro and small-sized enterprises is business sustainability. Several factors are threats to business continuity among micro and small sized enterprises; these are aggravated as they operate mostly at subsistent levels with minimal business capital at their disposal. Such businesses can easily go under when they face little crisis. Illiquidity of cash flow, theft, fire, and natural disasters and in this case epidemic or pandemic incidences can become life threatening to such businesses. Coronavirus pandemic is currently the biggest crisis affecting the whole world. It is impacting the economic life, the ways of life of most people and at least the psychological health of everyone.

There should be increased efforts towards understanding the impacts of specific factors on businesses and then formulating how to ameliorate such impacts is necessary to achieve the Sustainable Development Goals. Two of such goals directly relevant here are SDG1 and SDG8. SDG1 'End Poverty in all its forms everywhere' especially with regards to targets 1.1 and 1.5 are important (UN publication of SDG 2021). Similarly, SDG8 (especially Target 8.3) equally promotes entrepreneurship and encourages the formalization and growth of micro-, small- and medium sized enterprises, including improving their access to financial services (UN publication of SDG 2021).

This particular crisis is induced by a viral pandemic and because of its peculiarity and universal impacts, it is 
necessary to research all aspects of this incidence including its impact on businesses especially the vulnerable micro and small-sized enterprises.

The new virus, a global threat (Wang, 2020) caused by a novel Coronavirus, first detected in December 2019 around a seafood market in the Chinese city of Wuhan Hubei Province (Nishiura, 2020) is by far the largest outbreak with pneumonia-like presentation since the severe acute respiratory syndrome (SARS) outbreak in 2003. The new virus with symptoms of infection including fever, chills, cough, sore throat, breathing difficulty, nausea, vomiting, and diarrhoea was named as Severe Acute Respiratory Syndrome-Coronavirus (SARS-CoV2) or novel Coronavirus (2019-nCoV). It was designated by the World Health Organization (WHO) on 11th February 2020 as Coronavirus disease -19 (abbreviated "COVID-19") and officially declared as a pandemic on 11th March 2020 (WHO, 2020).

The Coronavirus (COVID-19) Pandemic affected the whole world suddenly, starting late in 2019 and as at $3^{\text {rd }}$ of April 2021, 131,104,484 people have been infected and 2,854,386 people had died from the disease worldwide. In Nigeria 163,063 persons have been infected and 2,058 have died from the disease (Worldometer, 2021). In Nigeria, COVID-19 incident occurred in January 2020 and same month it arrived Port Harcourt city. The virulence was so severe that many businesses were negatively impacted. Apart from the direct impacts of COVID-19 protocols requiring unfriendly attitudes of safe distancing, frequent washing of hands/use of sanitizers and wearing of facemasks in most parts of the world including Nigeria and in Port Harcourt, it affected people psychologically making them lose interest in active human interactions except when it was inevitable, people equally lost interest in the acquisition of luxury goods and at the peak of the incidence people concentrated on only purchasing essential items. In places where the spread of the disease was considered uncontrolled, government also had to lockdown sections of such communities and sometimes the whole communities or a state to control the spread. While such restriction of movements appears more effective in reducing the spread, it came with unpleasant consequences including high economic costs and massive job losses. The nation as a result suffered decline in economic activities in every sector which invariably affected the Gross National Product (GDP) negatively.

It was however observed that in certain quarters, since one man's poison is said to be another's meat, certain businesses could benefit and would find the circumstance favourable by the increased needs of their services and this implies that there may be greater patronage of their services as a result of the COVID-19 pandemic and its accompanied mobility restrictive measures.

Port Harcourt is one of the key revenue generating cities of Nigeria and is equally very active commercially. Port Harcourt, like every city and town in Nigeria, has all sorts of businesses being run by private entities. However, majority of these businesses are micro-sized, small-sized or medium-sized enterprises. These small businesses (micro and small-sized enterprises) are the largest employers of labour in the nation. As is the case in many developing countries, the micro-sized businesses which are often informal firms, are by far more preponderant in number. It is therefore important to understand how these micro and small-sized businesses thrive in the face of crisis, especially the on-going COVID-19 pandemic. Initially, a systematic search to accumulate a relatively complete body of relevant scientific literature was made. The methodology adopted was largely survey-based research. Such information will help people better prepare in case a similar incidence like this occurs again.

Considering the importance of micro and small businesses to the economy of the nation, we used Port Harcourt as our area of study to address the following research objectives:

1. Understand if sizes of these smaller businesses affect the ability of enterprises to survive in crisis using COVID-19 as the test case.

2. Understand if types of these smaller businesses affect the ability of the enterprise to survive in the COVID-19 related crisis.

3. To gather the perspectives of the micro/small-sized enterprise owners/managers on how government can support businesses to better survive in such situations.

\section{Literature Review}

\subsection{The Role of Micro-. Small and Medium Enterprises in Supporting Sustainable Development}

Clark (2018) stated that Micro-, Small and Medium Enterprises (MSMEs) contribute greatly to economic growth, job creation, poverty alleviation and inequality reduction. Clark (2018) went on to cite OECD report which noted that 53\% and $86 \%$ of employment opportunities in OECD countries such as UK and Greece in 2017 respectively were from those of MSMEs. They equally stated that $98 \%$ of all private enterprises in developing nations like Peru are MSMEs and MSMEs account for $60 \%$ and $80 \%$ of employed people in Peru and Kenya respectively. Clearly, 
MSMEs directly benefit the poor and vulnerable. We equally support the position of Clark (2018) that MSMEs support the following Sustainable Development Goals (SDGs): SDG 1 (End poverty), SDG 2 (Zero hunger), SDG 3 (Good health and well-being), SDG 8 (Promote inclusive and sustainable economic growth, employment and decent work), and SDG 9 (Improve sustainable industrialization and fostering innovation).

\subsection{Crisis}

Although conditions that make up crisis are not easily agreed upon, Simola (2013) opined that: high impact, ambiguous, urgent, rare, significant and involving stakes are characteristics which indicate crisis. Crisis involves a period of discontinuity, a situation where the core values of the organization are under threat. According to Karam (2018) crisis refers to as a low probability-high impact occurrence that threatens the viability of the organization. During crisis, there is a destabilizing effect to the organization and its stakeholders and an escalation of one or more issues, errors or procedures are expected during this period (Kayes, Allen, \& Self, 2012).

Crisis is seen as an inescapable interruption that every system is bound to encounter at any point in their life time and this most times occurs with or without sufficient warning signals. This confirms Oparanma and Wechie (2014) position that, it is impossible for an organization to operate without the occurrence of unexpected or unplanned business interruptions like strikes, layoffs, allegation of misconduct, products recalls, equipment explosions, and government policies - and in this case a pandemic. Wobodo, Asawo \& Asawo (2018) opined that a social system must interface regularly with its operating environment in order to achieve success. Thus, whatever happens in the environment always has an impact on the organization's survival. According to Lerbinger (2012), organization crisis can be categorised into eight types namely: natural disaster, technological crises, confrontation, malevolence, organizational misdeeds, workplace violence, terrorist attacks.

\subsection{The Global Impact of COVID-19}

The world is currently dealing with the reality of the Coronavirus (COVID-19) pandemic, a natural crisis, which has led to a huge economic loss for thousands of businesses across the globe. This loss is out-rightly attributed to the government's order of shutting down business operations (Tashanova, Sekerbay, Chen, Luo, Zhao, \& Zhang, 2020). In Nigeria, it was the same scenario as states that are major economic hubs were on lockdown as a result of the upsurge of the virus. This lockdown which featured the restriction on transportation of people and goods, significantly disrupted outputs and exports, and hindered the growth of private businesses by undercuts in the investments due to the loss of investors' confidence in the market (Jung, Park, Hong \& Hyun, 2016).

Against the backdrop of government lockdown and a halt of business activities, private businesses, financial and non-financial performances were affected. There was sharp decline in sales, which would subsequently lead to insufficient cash flow in carrying out various operations, financing and investing activities. Inventory became obsolete and this led to a loss in economic value. The financial implication as a result of the decrease in the sale will ultimately lead to private businesses pack-up and downsizing which will cause job loss (increase in unemployment). The main thrust of this article is to empirically ascertain the effect of COVID-19 pandemic on micro and small-sized enterprise survivability/sustainability in Port Harcourt, Nigeria and to the best of researchers' knowledge, there does not exist any previous study investigating this area in Nigeria.

\subsection{Impact of Covid-19 on the Economy}

The Coronavirus pandemic has had great impact on Nigeria stock market; this has attracted a lot of scholars to investigate the pandemic. Ozili and Arun (2020) studied the impact of COVID-19 on the global economy, which revealed that COVID-19 has huge negative impact on Nigeria stock market in which the virus compelled the enforcement of social distancing leading to closures of financial markets, corporate offices, businesses and events. The speed with which the virus spread exponentially among people resulted in decline in consumption and investment among investors, consumers and trade partners.

Similarly, Chukwuka and Ekeruche (2020) researched on understanding the impact of the COVID-19 outbreak on the Nigerian economy, the study showed that Nigeria's economy was estimated to have GDP increase in 2020 of $2.5 \%$. However, this was truncated by the pandemic and it led to high increase of the nation's debt services and revenue ratio at $60 \%$ amid the falling prices of oil. This study is consistent with Oladeinde (2020) who examined Coronavirus impact. They reported that Nigeria had to cut its Oil benchmark to $\$ 30$, slashing capital budget by $20 \%$ and changing its 2020 budget significantly to contain the effect of the outbreak on the nation's economy. The benchmark for crude which was initially placed at $\$ 57$ per barrel was later dropped down to $\$ 30$ per barrel, showing that Nigeria will experience much reduction in the revenue and project completion than what was initially planned. The report of International Monetary Fund (IMF) also showed that global growth will fall 
by $0.5 \%$ in 2020 due to the COVID-19 pandemic. The effects show that there will be stiffness and sharp decrease in the demand of commodities. It was predicted that by the first half of the year, the global economy, that of Nigeria inclusive, might enter into recession, as the result of huge inability to process raw material and respond to high demand of certain goods and services.

Akanni and Gabriel (2020) investigated the implication of COVID-19 on the Nigerian economy and discovered that COVID-19 pandemic led to disruption of activities and economic instability. It was seen that factors like social distancing, stay at home, limitation in spending and supply factor which include cutting or stopping production and output, have negative impact on economic growth. These have led to increasing poverty and unemployment rate. The National Bureau of Statistics (NBS) report 2020 placed Nigeria 21 among 181 counties with high unemployment rate of $23.1 \%$; it is estimated that about 87 million Nigerians are surviving with less than $\$ 2$ a day benchmark. Also globally, businesses cancelled trade shows and conferences which resulted in cancelled trips. At the beginning of the year 2020, first quarter to be precise, the International Air Transport Association (IATA), which represents global airlines, boosted its estimates of the global financial hit of COVID-19 from $\$ 29.3$ billion to $\$ 63$ billion to $\$ 113$ billion as the bookings keep falling beyond China and Asia at large. That would place businesses of airlines in their most unsafe situation since after the situation of September 11, 2001 attacks.

The COVID-19 pandemic in Nigeria has resulted in business leaders and owners having to swiftly mobilize and make short term decision. A decision such as the reduction in production output and or even shutting down operation temporarily could have long term implications that may not be foresighted. This, thus, would have an impact on private business financial performance, as a result of the lockdown policy or order by the President of the Federal Republic of Nigeria. Empirical studies have also suggested that both pandemics and epidemics harm the financial performance of all types of organizations. Kim, Kim, Lee and Tang (2020) investigated the influence of macroscopic and infectious epidemic disease outbreaks on the financial performance of the restaurant industry. Nine events on four epidemic disease outbreaks during 2004-2016 were analysed. Event study method and Mann-Whitney U test were used as the research method and inferential statistic respectively. What they found confirmed the negative influence of epidemic disease outbreaks on the restaurant industry, and identified all the three firm characteristics serve as risk-mitigating factors.

We can say that due to the continued progress being made towards effective vaccination, the impacts are seen to be slowing down and there is hope. That notwithstanding, such impacts on the national economy equally affects micro and small-sized enterprises because they do not exist in vacuum.

\subsection{Impact of COVID-19 on Micro and Small-Sized Enterprises}

Carter (2020) stated that small businesses are disproportionately responsible for job growth. Small companies create more than 1.5 million jobs annually in the United States. As more people work, GDP grows. He went further to explain that small businesses impact the local community of business owners. The more businesses thrive, the more there is increased economic activities which equally impact other service providers.

BusinessWire (2020) equally reported that small and medium-sized businesses in the U.S. had disproportionate impact from the COVID-19 pandemic, with over $43 \%$ surveyed reporting a significant to severe impact. Majority $(84 \%)$ of businesses surveyed realized some impact from the pandemic and resultant economic downturn. Smaller businesses with 1-4 employees were most impacted. The businesses were helped by the Payroll Protection Program in the United States of America.

The impact of COVID-19 in Africa may not have been at the same level like it was in America and Europe but the impact caused many nations in Africa to curtail movements at the pick of the pandemic to prevent spread. Lakuma and Sunday (2020) wrote that Uganda similarly used a number of measures to control the spread. These measures included the closure of schools, restrictions on internal and international travel, use of hand sanitizer, improved hand-washing stations, social distancing, and even lockdown, among others. The measures may have contributed to control the spread of the virus but equally negatively affected economic activities. A survey by the Economic Policy Research Centre (EPRC) in Uganda equally showed that three-quarters of the surveyed businesses laid-off employees due to the risks presented by COVID-19 and measures taken by government etc. to contain the spread.

According to Amuda \& University (2020) in Nigeria the outbreak of COVID-19 affected every facet of life: education, social activities, political, governance, and economic dealings. Most businesses recorded low sales and most SMEs reported decline in the source of income. There have been economic challenges for businesses and the COVID-19 pandemic worsened the situation heightening the need for government interventions.

The benefits enjoyed by businesses in places like United States of America may not be available to most 
business owners in developing countries for example in Nigeria and some of these businesses (whose owners/managers were interviewed for this research) are informal and may not have opportunity to transparently benefit from such support if made available by the Nigerian government.

Business environments are not static and changes can occur suddenly which may affect business survivability positively or negatively. Business owners and managers play major roles in ensuring that businesses survive during negative changes. That is the essence of managing business proactively and managing crisis effectively.

\section{Methodology}

\subsection{Research Design Analysis}

This research is aimed at finding out how COVID-19 affected micro and small sized enterprises in Port Harcourt. We interviewed 568 enterprise units covering 11 classes of businesses that represent most of the micro and small-sized businesses in Port Harcourt. We also interviewed the business owners or their managers to get first-hand information from them. We adopted both quantitative and qualitative analysis depending on the nature of the question. The quantitative data collected from the interviews were statistically treated to means (Ahiauzu $\&$ Asawo, 2016). Both quantitative and qualitative data were collated and analysed using appropriate graphical presentations to highlight the relevant issues (Genise, 2002)

Micro-sized and Small-sized businesses or enterprises are non-subsidiary, independent units with very few persons under their employment. The classification in terms of what is Micro, Small or Medium sized enterprise depends on the country in question. It is difficult to get a uniform classification of enterprise sizes in the world. Often the size of the economy and the Gross Domestic Product (GDP) of a nation affect such classification/definition. OECD (2005) had classified small businesses as those with less than 50 employees and micro-sized businesses as those with less than 10 employees. This aligned a little more with the methods used by Nigerian commercial banks for their operational purposes. The number of employees that constitute small business for big economies like the European Union, United States of America and Canada with those of World Bank/other international financial outfits is far higher.

For this research, we considered the level of businesses and the GDP of Nigeria in the classification of the businesses. In this regard we considered businesses with 8 or less employees as micro-sized while those having between 9 and 20 as small-sized. These two categories are the target sizes of businesses utilised by the research.

\subsection{Data Collection}

We conducted face to face interviews for these business owners and managers using the pre-set questionnaire developed for this research (Hennink et al., 2011). These interviews were conducted to understand how the COVID-19 impacted their businesses from September to December 2020.

To answer these questions, we developed a set of objectives and generated question to help us elicit responses that will address the research questions for business owners and managers on how the COVID-19 pandemic affected their businesses.

The following are the questions grounding this research:

1) Did the COVID-19 pandemic affect the patronage of customers with regards to the size and type of the business?

2) Did the COVID-19 pandemic affect the ability of the business to get required supplies with regards to the size and type of the business?

3) Did the COVID-19 pandemic make the business to temporarily retrench staff and how did the size and type of the business contribute to this?

4) Did COVID-19 pandemic affect the level of profit made by the various sizes and types of the businesses compared to what was made before the pandemic?

5) What are your perceptions on how government can support you in case of another pandemic?

The questionnaires were administered to owners and managers of 568 micro and small-sized enterprises within the Port Harcourt metropolis as follows:

1. Fruit sellers

2. Artisans

3. Online shops/Bloggers

4. Chemist shops/Pharmacies 
5. Retail shops/Provision stores

6. Business centres

7. Petroleum product sellers/Filling stations

8. Meat and fish sellers

9. Drinks and Food shops

10. Retail Point of Sale System (POS) as a means of converting money in the bank to cash/Micro-Credit institutions

11. Pool Betting shops

For questions 1 to 4 , the responders were given a 7-point scoring scale to respond to the various research questions on how they performed in relation to the COVID-19 pandemic impacts as shown in the research questions developed/questionnaire.

- $\quad 3$ if they did well (Pandemic was highly favourable in relation to the issue)

- 2 if they did moderately well (Pandemic was favourable in relation to the issue)

- 1 if they manage to do well (Pandemic was only slightly favourable in relation to the issue)

- $\quad 0$ if it was just the same (Pandemic did not affect the business in relation to the issue)

- $\quad-1$ if they did a little poorly (Pandemic was slightly unfavourable in relation to the issue)

- $\quad-2$ if they did poorly (Pandemic was not favourable in relation to the issue)

- $\quad-3$ if they did very poorly (Pandemic was highly unfavourable in relation to the issue)

This scoring system $(+3$ as business doing very well, 0 as business not impacted by the treatment and -3 as business was most negatively affected) is an adaptation of the scoring system developed by Nilsson et al (2016) who used their scoring scale as shown in the table below. It will be recalled that Nilsson et al adopted a scoring scale similar to a semantic differential with a seven points scale. In their scale Zero shows no links between Sustainable Development Goals (SDGs) and their targets. In that scale, 3 shows very close additive links and -3 refers to very negative and subtractive links.

The table below is what Nilsson et al (2016) used:

Table 1. The seven types of interaction outcomes between SDG targets

\begin{tabular}{cl}
\hline Interaction Label & Meaning \\
\hline+3 & Progress on one target automatically delivers progress on another \\
+2 & Progress on one target makes it easier to make progress on another \\
+1 & Progress on one target creates conditions that enable progress on another \\
0 & There is no significant link between two targets' progress \\
-1 & Progress on one target constrains the options for how to deliver on another \\
-2 & Progress on one target makes it more difficult to make progress on another \\
-3 & Progress on one target automatically leads to a negative impact on another \\
\hline
\end{tabular}

In line with what Nilsson et al (2016) did Lawrence., Ihebuzor and Lawrence (2020) used a 4 points scale to compare the relationships between SDG16 and its targets on one hand and SDG16 Targets with the other SDGs and their targets on the other.

All the data obtained from the survey of this research were analysed using their means, standard deviation and assessed at 5\% probability of significance and then presenting them graphically. Questions 1 to 4 were analysed comparing the outcome from the micro-sized businesses to those of their relatively larger sized businesses in the same class and across the classes using means, standard deviations, $p=$ values. They were equally assessed graphically. For question 5, we grouped the similarity of suggestions given as regards how government can support their growth and prevent major impact if the incident occurs again and then graphically compared the frequency of these suggestions from the various types of businesses. 


\section{Findings}

4.1 Customers' Patronage during the Peak of COVID-19 Pandemic

Table 2. Summary of independent sample t-test on the mean difference between the SSB and MSB over Customers' patronage during the peak of COVID-19 Pandemic

\begin{tabular}{lllllllllll}
\hline & $\begin{array}{l}\text { Did the COVID19 pandemic affect the patronage of } \\
\text { customers to the business? }\end{array}$ & Mean & SD & N & Mean & SD & N & t & df & p-value \\
\hline SN & Fruit Sellers & -1.37 & 1.98 & 52 & -0.67 & 1.92 & 12 & -1.11 & 62 & 0.272 \\
$\mathbf{2}$ & Artisan/Skill workers & $-\mathbf{0 . 9 3}$ & $\mathbf{1 . 7 0}$ & $\mathbf{3 0}$ & $\mathbf{- 1 . 7 7}$ & $\mathbf{1 . 4 1}$ & $\mathbf{3 0}$ & $\mathbf{2 . 0 7}$ & $\mathbf{5 8}$ & $\mathbf{0 . 0 4 3}$ \\
3 & Online Businesses & -0.03 & 2.09 & 31 & -0.15 & 1.52 & 13 & 0.19 & 42 & 0.851 \\
4 & Pharmacy/Chemists & 0.48 & 2.15 & 29 & -0.27 & 2.23 & 30 & 1.31 & 57 & 0.194 \\
5 & Provision Retails & -1.27 & 1.70 & 33 & -0.80 & 1.97 & 15 & -0.85 & 46 & 0.400 \\
6 & Business centres & -1.71 & 1.19 & 31 & -0.95 & 1.53 & 21 & -2.00 & 50 & 0.050 \\
$\mathbf{7}$ & Petroleum Product Retails & $\mathbf{1 . 7 3}$ & $\mathbf{1 . 6 6}$ & $\mathbf{3 3}$ & $\mathbf{0 . 0 3}$ & $\mathbf{1 . 8 8}$ & $\mathbf{3 0}$ & $\mathbf{3 . 7 9}$ & $\mathbf{6 1}$ & $\mathbf{0 . 0 0 0}$ \\
8 & Meat/Fish Retails & -1.71 & 1.66 & 48 & -0.36 & 2.25 & 11 & -2.26 & 57 & 0.028 \\
9 & Bars/Eateries & -1.00 & 1.92 & 40 & -1.41 & 1.71 & 22 & 0.83 & 60 & 0.408 \\
$\mathbf{1 0}$ & POS/Micro Financing & $\mathbf{1 . 0 4}$ & $\mathbf{2 . 1 6}$ & $\mathbf{2 4}$ & $\mathbf{- 2 . 7 8}$ & $\mathbf{0 . 4 4}$ & $\mathbf{9}$ & $\mathbf{5 . 2 2}$ & $\mathbf{3 1}$ & $\mathbf{0 . 0 0 0}$ \\
11 & Pool betting shops & -1.36 & 1.36 & 11 & -2.17 & 0.83 & 12 & 1.72 & 21 & 0.100 \\
\hline
\end{tabular}

*Significant at .05 level of significance.

The result from Table 2 shows the summary of independent sample t-test on the mean difference between the MSB and SSB over Customers' patronage during the peak of COVID-19 Pandemic. It shows that the SSB and MSB differed over Customers' patronage during the peak of COVID-19 Pandemic amongst Artisan/Skill workers $(\mathrm{t}=2.07, \mathrm{p}=.043)$, petroleum product retails $(\mathrm{t}=3.79, \mathrm{p}=0.000)$ and POS/Micro Finance $(5.22, \mathrm{p}=.000)$ respectively.

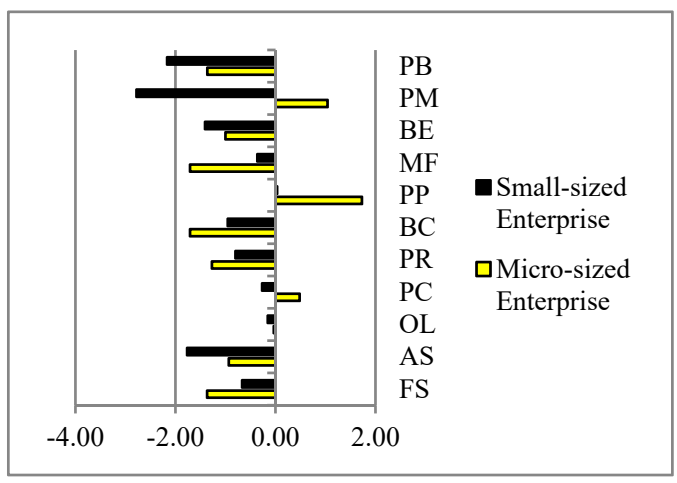

\begin{tabular}{|l|l|}
\hline Types of business & Code \\
\hline Pool Betting shops & BP \\
\hline POS/Micro Finance & PM \\
\hline Bars/Eateries & BE \\
\hline Meat/Fish Retails & MF \\
\hline Petroleum Products & PP \\
\hline Business Centres & BC \\
\hline Provision Retails & PR \\
\hline Pharmacy/Chemists & PC \\
\hline Online Businesses & OL \\
\hline Artisans/Skills & AS \\
\hline Fruits Sellers & FS \\
\hline
\end{tabular}

Figure 1. COVID-19 impact on Customers' patronage

The most outstanding observation in Figure 1 is that three of the micro-sized businesses had more customer patronage as a result of the pandemic. They include Point of Sale System (POS), petroleum retail outlets and micro-sized drug stores.

The figure showed that most businesses evaluated suffered from the impact of the pandemic in terms of customers' patronage. The micro-sized businesses did better than the relatively bigger ones that were tagged as small-sized businesses in line with the classification in the following enterprises: Pool betting, Micro-financing, Restaurants/Bars, Pharmacies, Online businesses and artisans. On the other hand, the micro-sized businesses of Meat/Fish selling, Business Centres, Provision stores and Fruit selling did not perform as well as the relatively larger sized units (small-sized businesses). 


\subsection{Getting Supplies as and When Due during the COVID-19 Pandemic}

Table 3. Summary of independent sample t-test on the mean difference between the MSB and SSB over supplies as when due during the COVID-19 pandemic

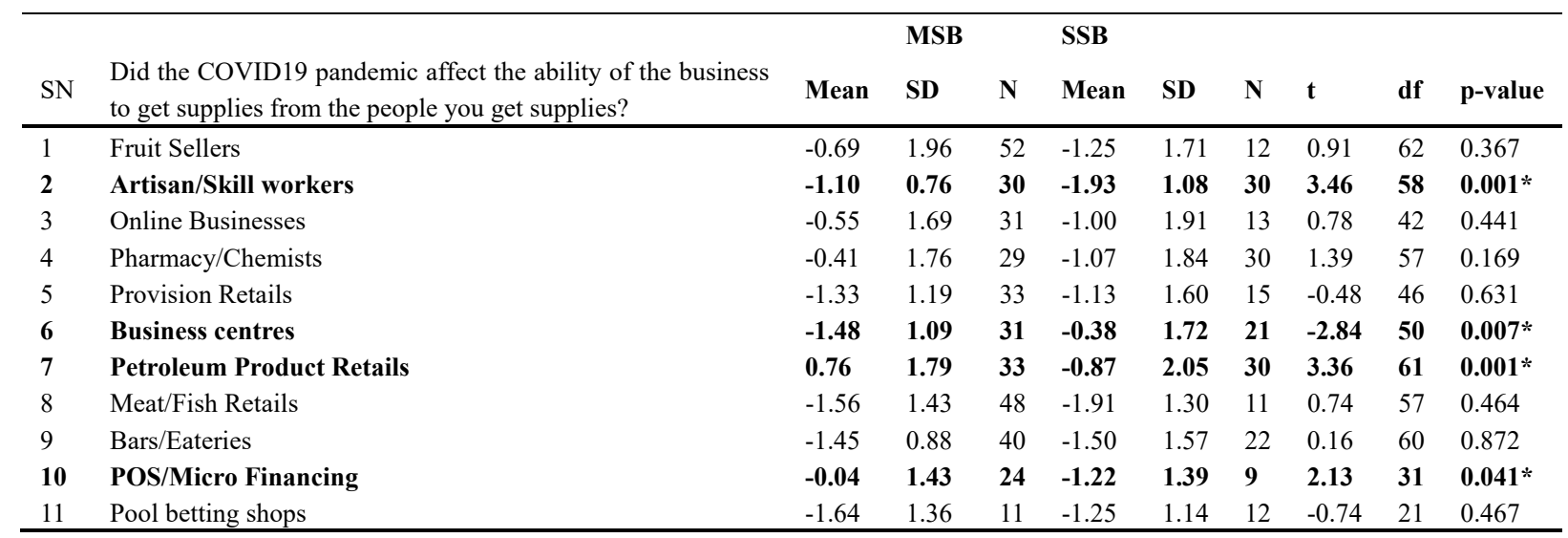

*Significant at .05 level of significance.

The result from Table 3 shows the summary of independent sample t-test on the mean difference between the SSB and MSB over supplies as when due during the COVID-19 Pandemic. It shows that the SSB and the MSB difference over supplies as when due during the COVID-19 Pandemic, specifically among Artisan/Skill workers $(\mathrm{t}=3.46, \mathrm{p}=.001)$, Business centers $(\mathrm{t}=-2.84, \mathrm{p}=.007)$, Petroleum Product Retails $(\mathrm{t}=3.36, \mathrm{p}=.001)$ and POS/Micro Financing $(\mathrm{t}=2.13, \mathrm{p}=.041)$ respectively.

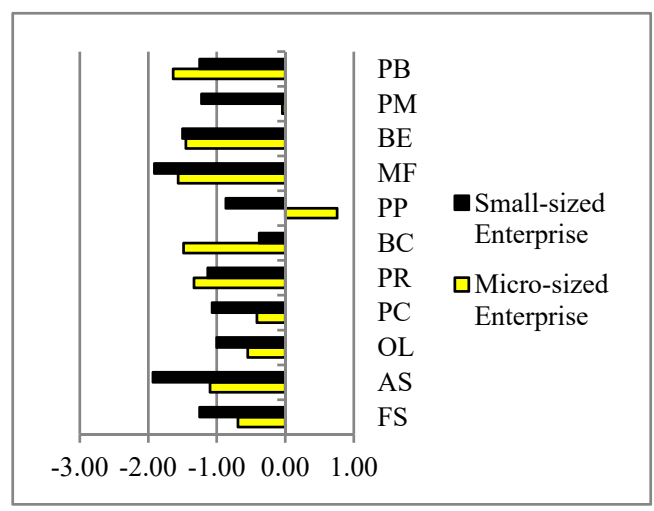

\begin{tabular}{|l|l|}
\hline Types of business & Code \\
\hline Pool Betting shops & BP \\
\hline POS/Micro Finance & PM \\
\hline Bars/Eateries & BE \\
\hline Meat/Fish Retails & MF \\
\hline Petroleum Products & PP \\
\hline Business Centres & BC \\
\hline Provision Retails & PR \\
\hline Pharmacy/Chemists & PC \\
\hline Online Businesses & OL \\
\hline Artisans/Skills & AS \\
\hline Fruits Sellers & FS \\
\hline
\end{tabular}

Figure 2. COVID-19 impact on availability of supplies

Figure 2 shows that all the businesses had difficulty in getting supplies especially during the lockdown. However, the information indicates that the micro-sized businesses were more able to go around it better than the small businesses. The outstanding observation is that micro-sized petroleum product sellers benefitted from the COVID-19 pandemic lockdown and did not suffer from getting their regular supplies. 


\subsection{Temporarily Retrenched Workers during the Peak of the COVID-19 Pandemic}

Table 4. Summary of independent sample t-test on the mean difference between the SSB and MSB over temporarily retrenched workers during the peak of the COVID-19 Pandemic

\begin{tabular}{|c|c|c|c|c|c|c|c|c|c|c|}
\hline $\mathrm{SN}$ & Did the COVID19 pandemic make you retrench staff? & Mean & $\begin{array}{l}\text { MSB } \\
\text { SD }\end{array}$ & $\mathbf{N}$ & $\begin{array}{l}\text { SSB } \\
\text { Mean }\end{array}$ & SD & $\mathbf{N}$ & $\mathbf{t}$ & df & p-value \\
\hline 1 & Fruit Sellers & 0.21 & 1.59 & 52 & -1.42 & 0.51 & 12 & 3.49 & 62 & 0.001 \\
\hline 3 & Online Businesses & -0.16 & 0.69 & 31 & 0.23 & 0.44 & 13 & -1.89 & 42 & 0.065 \\
\hline 4 & Pharmacy/Chemists & 0.14 & 0.83 & 29 & -0.70 & 0.99 & 30 & 3.52 & 57 & 0.001 \\
\hline 5 & Provision Retails & -0.67 & 0.96 & 33 & -0.80 & 1.47 & 15 & 0.38 & 46 & 0.709 \\
\hline 7 & Petroleum Product Retails & 0.00 & 1.06 & 33 & -0.87 & 1.59 & 30 & 2.56 & 61 & 0.013 \\
\hline 8 & Meat/Fish Retails & -0.81 & 1.35 & 47 & -1.45 & 1.51 & 11 & 1.40 & 56 & 0.166 \\
\hline 9 & Bars/Eateries & -0.67 & 0.84 & 39 & -1.32 & 1.99 & 22 & 1.79 & 59 & 0.078 \\
\hline 10 & POS/Micro Financing & -0.08 & 0.58 & 24 & -2.11 & 0.60 & 9 & 8.82 & 31 & 0.000 \\
\hline 11 & Pool betting shops & -0.91 & 1.22 & 11 & -1.25 & 1.60 & 12 & 0.57 & 21 & 0.575 \\
\hline
\end{tabular}

*Significant at .05 level of significance.

The result from Table 4 shows the summary of independent sample t-test on the mean difference between the MSB and SSB over temporarily retrenched workers during the peak of the COVID-19 Pandemic. It shows that the $\mathrm{m}=\mathrm{SSB}$ and the $\mathrm{m}=\mathrm{MSB}$ differed over temporarily retrenched workers during the peak of the COVID-19 Pandemic amongst Fruit Sellers $(t=3.49, \mathrm{p}=.001)$, Artisan/Skill workers $(\mathrm{t}=3.26, \mathrm{p}=.002)$, Pharmacy/Chemists $(\mathrm{t}=3.52, \mathrm{p}=.001)$, Petroleum Product Retails $(\mathrm{t}=2.56, \mathrm{p}=0.013)$ and POS/Micro Financing $(\mathrm{t}=8.82, \mathrm{p}=.000)$ respectively.

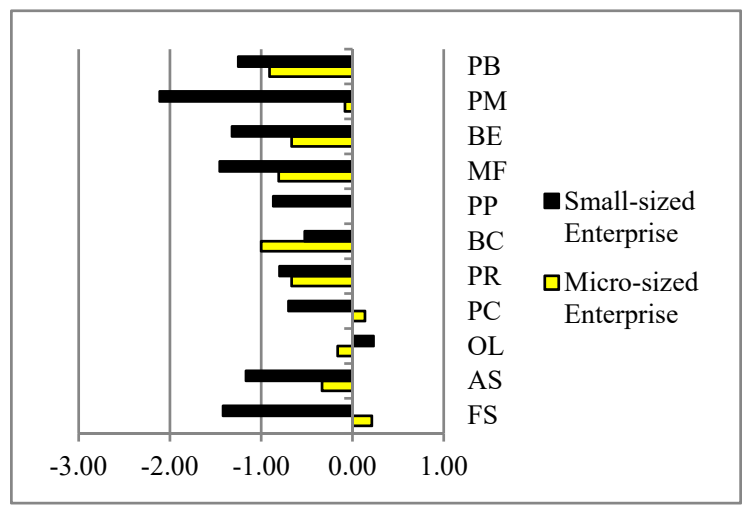

\begin{tabular}{|l|l|}
\hline Types of business & Code \\
\hline Pool Betting shops & BP \\
\hline POS/Micro Finance & PM \\
\hline Bars/Eateries & BE \\
\hline Meat/Fish Retails & MF \\
\hline Petroleum Products & PP \\
\hline Business Centres & BC \\
\hline Provision Retails & PR \\
\hline Pharmacy/Chemists & PC \\
\hline Online Businesses & OL \\
\hline Artisans/Skills & AS \\
\hline Fruits Sellers & FS \\
\hline
\end{tabular}

Figure 3. COVID-19 impact on business ability to retain workers

Figure 3 showed the level of impact suffered by businesses during the period. Some of them had to lay off workers on a temporary basis to reduce cost since revenue is low or non-existent. Three of the businesses (two in the micro-sized category - Drug stores and Fruit sellers) and online businesses in the relatively lager category performed better than the rest. All the others in one way or the other retrenched their workers. 


\subsection{Comparison Level of Profit Made before and during the COVID-19 Pandemic}

Table 5. Summary of independent sample t-test on the mean difference between the SSB and MSB over profit made before and during the COVID-19 pandemic

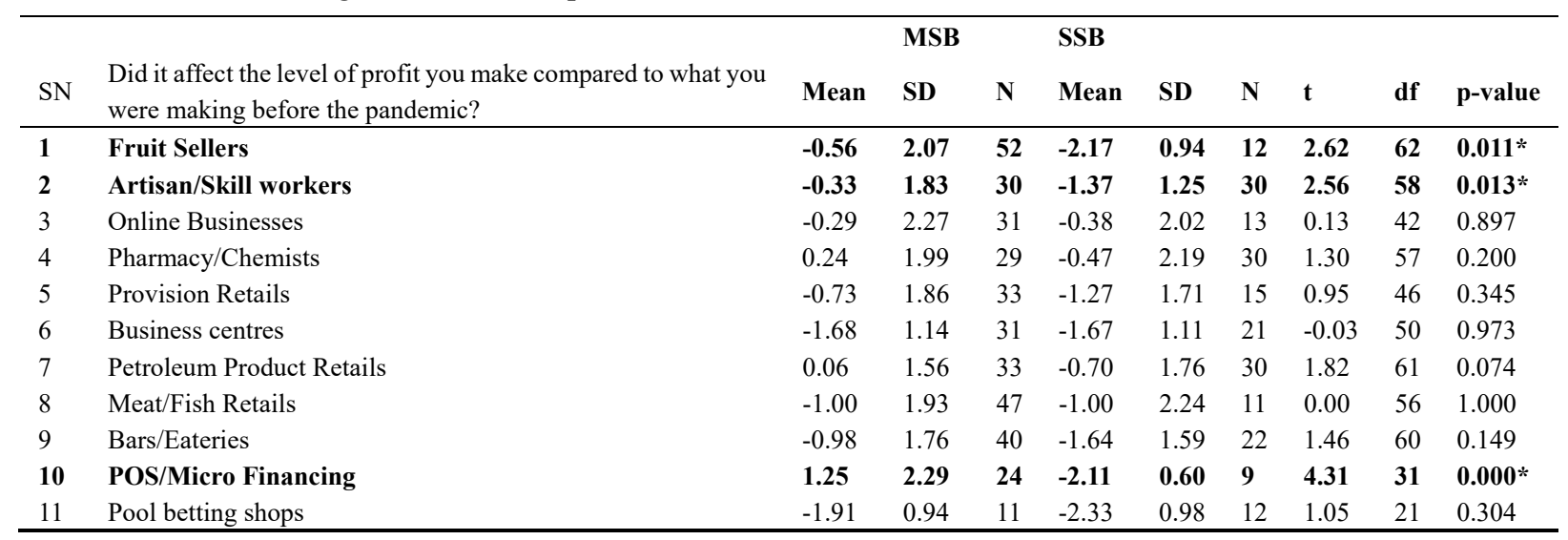

The result from Table 5 shows the summary of independent sample t-test on the mean difference between the MSB and SSB over profit made before and during the COVID-19 pandemic. It shows that the SSB and MSB differed over profit made before and during the COVID-19 pandemic amongst Fruit Sellers $(\mathrm{t}=2.62, \mathrm{p}=.011)$, Artisan/Skill workers $(\mathrm{t}=2.56, \mathrm{p}=.013)$ and POS/Micro Financing $(\mathrm{t}=4.31, \mathrm{p}=.000)$ respectively.

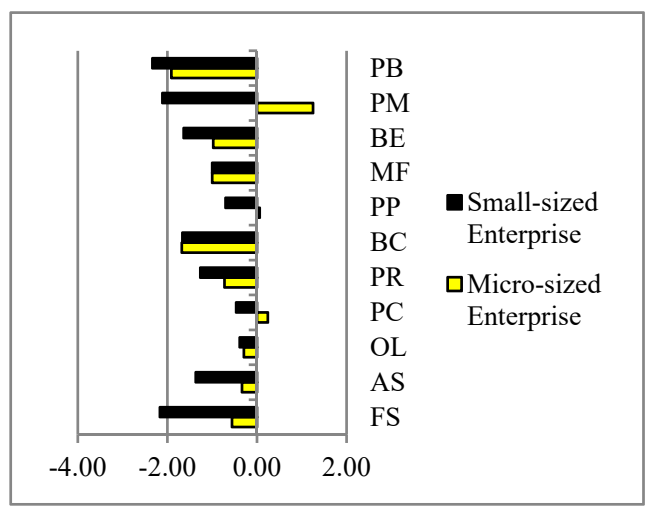

\begin{tabular}{|l|l|}
\hline Types of business & Code \\
\hline Pool Betting shops & BP \\
\hline POS/Micro Finance & PM \\
\hline Bars/Eateries & BE \\
\hline Meat/Fish Retails & MF \\
\hline Petroleum Products & PP \\
\hline Business Cera图表区 & BC \\
\hline Provision Retails & PR \\
\hline Pharmacy/Chemists & PC \\
\hline Online Businesses & OL \\
\hline Artisans/Skills & AS \\
\hline Fruits Sellers & FS \\
\hline
\end{tabular}

Figure 4. COVID-19 impact on business profitability

Figure 4 showed that only three micro-sized businesses reported to have benefited from the COVID-19 pandemic. The business that thrived most is the POS, the other two businesses that made some profit and did not suffer losses are those that retail petroleum products on small scale and the drug retail shops.

\subsection{Suggestions of Government Interventions that can Reduce Impact of COVID-19 Related Crisis in the Future}

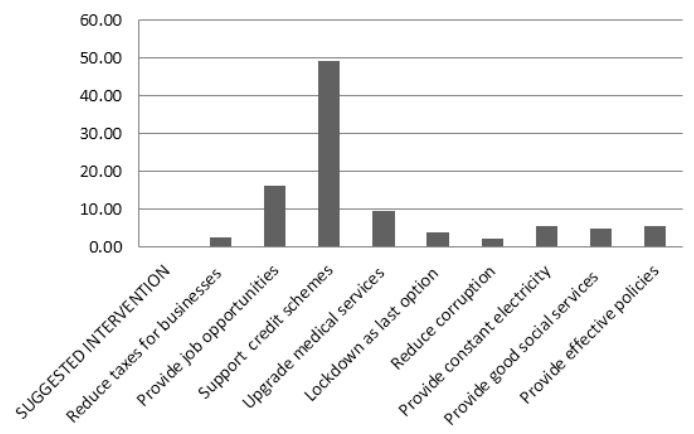

Figure 5. Suggested interventions by business owners for government to ameliorate impact in pandemic 
We asked the business owners on their perspectives of how government can support their businesses during this or future incidences and clearly most of them felt all they need is financial support in forms of soft loans to help them stay in business. They also related this to the provision of palliatives which was not received. It is in that light that some of them insisted on the need for government to fight corruption so that interventions can get to the target beneficiaries.

A lot of them also asked for reduced taxes and effective policies to help grow businesses. Others went outside these areas to ask for developmental interventions like upgrading of medical infrastructure and services, provision of social and physical infrastructures (constant electricity supply, roads, industries, employment etc.)

\section{Discussions}

\subsection{Customers' Patronage during the Peak of COVID-19 Pandemic}

The Point of Sale System (POS), that is places other than banks people go with the ATM/Credit cards for financial transactions, had more customers and this is likely because the banks were closed and such outlets helped people to get cash. The other group that benefited from the pandemic were petty sellers of petroleum products. This is related to the fact that people needed fuel even in the lockdown to power their generators for electricity supply. Another group that benefited from the pandemic were micro-sized drug stores, where people seek medical intervention in the hope of preventing the disease or attending to other ailments.

\subsection{Getting Supplies as and When Due during the COVID-19 Pandemic}

The reason why micro-sized petroleum product sellers benefitted from the COVID-19 pandemic lockdown and did not suffer from getting their regular supplies has something to do with their selling illegally obtained or locally refined products which they sell to unsuspecting customers.

\subsection{Temporarily Retrenched Workers during the Peak of the COVID-19 Pandemic}

Micro-sized businesses by nature have fewer workers and some were using family members to help in the businesses, this may account for the wide disparity in the poor performance of the relatively larger businesses with regards to retrenching workers to stay afloat.

It was observed that micro-sized drug stores were not affected for the reason that business was booming and micro-sized fruit sellers too were not affected because they did not hire workers but use family members to sell their goods. For the online businesses they also did not do badly as many people opted to order for things online instead of exposing themselves by physically going to the stores or markets. The lockdown opened up that business area more as more people, organizations, schools, churches etc. went online to carry out their business services.

\subsection{Comparison of Profit Levels Made Before and during the COVID-19 Pandemic}

The business that thrived most is the POS business where people withdraw cash or make other financial transactions using the ATM/Debit cards. Since the Banks' ATM points are overcrowded and many are mindful of the need for safety to avoid infection. This was the main way to get or transfer money during the period banks were closed down. Even after the banks were opened, the restrictions and the COVID-19 protocols put in place by government made, and strictly adhered to by the banks, made getting money from the banks relatively tedious, many resorted to the continuous using of these POS outlets for their financial transactions.

The micro-sized drug shops and sellers of petroleum products equally benefited from the impacts of the pandemic as many people resorted to patronizing them thereby enhancing the profitability of such businesses.

It was observed that none of the relatively bigger businesses, also classified as small-sized businesses, profited from the pandemic. As stated earlier, among the 11 types of micro-sized businesses assessed only 3 benefited. We can therefore say, businesses did poorly as a result of the pandemic. Another observation is that there is a general trend that the micro-sized businesses survived better than their relatively larger counterparts.

\subsection{Suggestions of Government Interventions that can Reduce Impact of COVID-19 Related Crisis in the Future}

Business sustainability is a complex phenomenon and it becomes even more complicated for small sized businesses. A good portion of these businesses are informal having very few persons manning them and these persons do not have any elaborate business skills to effectively manage these businesses. They buy and sell and the revenue generated sometimes are equally utilised to solve other pressing family issues. Their businesses therefore often go down under the slightest crisis. Profitability does not make sense if the income is consumed and none of the income is ploughed back to sustain and grow the business. Clearly the COVID-19 crisis affected these businesses adversely and profoundly. 


\section{Conclusion}

Coronavirus pandemic is one of the major threats that are militating against the effective achievement of the Sustainable Development Goals. The pandemic affected all the facets of sustainability: it is an environmental and biological threat to humanity; it affects humanity negatively in the effective pursuit of healthy living as well as in the physical and mental senses and also at the economic development realm. Businesses were affected and small-sized businesses are vulnerable.

In all the businesses assessed, the smaller micro-sized businesses were more successful than the small-sized businesses in terms of their abilities to retain customers, get necessary supplies, retain workers and eventually make profit during the COVID-19 pandemic. Even though all the businesses were negatively affected, the micro-sized ones fared better.

In terms of the nature or types of businesses, those whose products were considered more essential, especially in such lockdown and health related circumstances, like those selling fruits that people patronised to stay healthy, the online enabled businesses that do not necessarily require physical interactions as a condition to do deals, the POS as alternative cash transaction points, those selling drugs for health related purposes and those selling petroleum products as source of fuel for electricity generators, thrived better than others who are into business centres, micro-finance, pool betting, or artisan workers etc.

Considering the subsistent level of their existence, their major needs are availability of credit and other support including provision of palliatives for business operations, this is the area that government should look at to sustainably grow the economy. They also complained that the little government did was not felt because it did not get to those who needed help most. Many of them also complained about the effects of corruption on national development and how several credit and grant interventions for businesses and agriculture were misappropriated using ghost names. They perceived that they cannot vouch for the effective delivery of the palliatives given during the peak of the COVID-19 crisis. Other frequently suggested areas for government's interventions were provision of job opportunities, upgrading of medical facilities and services, reduction of taxes for small businesses, provision of effective policies to sustainably develop businesses and provision of development amenities.

Crisis is part of life and our ability as entrepreneurs and government to proactively and effectively manage them when they occur will help in the sustainability of businesses. We therefore need to ensure that everyone acquires business/entrepreneurship skills to survive business related crises.

\section{Recommendations}

Government should try and develop more sustainability friendly policies for business development and industrial growth in the country. As more industries become operational and there is increased economic activities; more micro and small-sized businesses that provide support to these businesses or services to the workers/bigger contractors will spring up and thrive.

Government must do all within its powers to ensure that interventions to benefit small and medium-sized businesses and the poor masses get to them by plugging all loopholes for misappropriation.

Employment opportunities will continue to dwindle with the continuously increasing population pressure in Nigeria and that will only mean more people sliding into poverty if stable and sustainable economic activities are not encouraged by all. Through the introduction of basic business/entrepreneurial skills capacity building into the educational curricula at every level from nursery to university undergraduate education and also encouraging mass education/sensitization programmes on the need for all business owners to acquire this set of important skills to remain in business is important.

\section{Acknowledgements}

We wish to thank Dame Dr Mercy Oke-Chinda and Dr Christy George for finding time to go through this work and we value the useful corrections made. We also thank Dr Wonu Nduka who analysed the research data statistically. 


\section{References}

Ahiauzu, A. I., \& Asawo, S. P. (2016). Advanced Social Research Methods. Port Harcourt, Rivers: CIMRAT.

Alves, J. C., Lok, T. Ch., Luo, Y. B., \& Hao, W. (2020). Crisis Management for Small Business during the COVID-19 Outbreak: Survival, Resilience and Renewal Strategies of Firms in Macau. https://doi.org/10.21203/rs.3.rs34541/v1

Amesi, J., \& Augustus, A. (2015). Crisis Management and Conflict Resolution Strategies in Business Organizations in Rivers State.

Amuda, Y. J., \& University, P. S. (2020). Impact of Coronavirus on small and medium enterprises (SMEs): Towards post-COVID19 economic recovery in Nigeria. Academy of Strategic Management Journal, 19(6).

Bailey, V. (2016). Proactive or Reactive Leadership, which is Most Effective in the Workplace? Retrieved from https://blog.vistage.co.uk/proactive-or-reactive-leadership-which-is-most-effective-in-the-workplace

Bartik, W., A., Bertrand, M., Cullen, Z., Glaeser, G., L., Luca, M., \& Stanton, C. (2020). The Impact of COVID-19 on Small Business Outcomes and Expectations. Proceedings of the National Academy of Sciences of the United States of America. https://doi.org/10.1073/pnas.2006991117

Business Wire. (2020) Small Businesses Feel Biggest Impact of Coronavirus Pandemic. Business Wire. Retrieved from

https://www.businesswire.com/news/home/20201008005232/en/Small-Businesses-Feel-Biggest-Impact-ofCoronavirus-Pandemic

Carter, T. (2020). Entrepreneur Leadership Network Contributor. Entrepreneur Media. Retrieved from https://www.entrepreneur.com/article/363407

Chukwuka, O., \& Ekeruche, M. A. (2020). Understanding the Impact of the COVID-19 outbreak on the Nigerian economy. Brookings Institution.

Clark, K. L. (2018). Policy Brief of the Department of Economic and Social Affairs - Sustainable Development of the United Nations: The Role of Micro-Small and Medium Enterprises in Achieving SDGs- Micro-, Small and Medium Enterprises (MSMEs) and their potential contributions to SDGs.

Genise, P. (2002). Usability Evaluation: Methods and Techniques. Technical Paper. University of Texas, USA.

Hennink, M., Hutter, I., \& Bailey, A. (2011). Qualitative Research Methods. London: Sage publications Ltd.

Herbane, B. (2013). Exploring crisis management in UK small-and-medium-sized enterprises. Journal of Contingencies and Crisis Management, 21(2), 82-95.

Hong, P., Huang, C., \& Li, B. (2012). Crisis management for SMEs: insights from a multiple-case study. International Journal of Business Excellence, 5(5), 535-553.

Irvine, W., \& Anderson, A. R. (2006). The impacts of foot and mouth disease on a peripheral tourism area: Therole and effect of crisis management. Journal of Travel \& Tourism Marketing, 19(2-3), 47-60.

Jung, H., Park, M., Hong, K., \& Hyun, E. (2016). The impact of an epidemic outbreak on consumer expenditures: An empirical assessment for MERS Korea. Sustainability, 8(454), 1-15. https://doi.org/10.3390/su8050454

Karam, M., G. (2018). The Impact of Strategic Planning on Crisis Management Styles in the 5-Star Hotels. Journal of Hotel \& Business Management, 7(1). https://doi.org/10.4172/2169-0286.1000171

Kayes, D., C., Allen, N. C., \& Self, N. (2012). Integrating Learning, Leadership, and crisis in management education: Lessons from army officers in Iraq and Afghanistan. Journal of Management Education, 37(2). https://doi.org/10.1177/1052562912456168

Khaled, Z., \& Tevhide, S. G. (2014). Crisis Management: A Historical and Conceptual Approach for a Better Understanding of Today's Crises, Crisis Management - Theory and Practice, Katarina Holla, Michal Titko and Jozef Ristvej, IntechOpen. https://doi.org/10.5772/intechopen.76198

Kim, Y. J., Jeong, Y. J., Kim, S. H., Kim, Y. J., Lee, S. Y., Kim, T. Y., Choi, M. S., \& Ahn, J. H. (2020). Preparedness for COVID-19 infection prevention in Korea: a single-centre experience. J Hosp Infect., 105(2), 370-2. https://doi.org/10.1016/j.jhin.2020.04.018

Lakuma, P. C., \& Sunday, N. (2020). Impact of COVID-19 on micro, small, and medium businesses in Uganda. Brookings

Institution.

Retrieved

from 
https:/www.brookings.edu/blog/africa-in-focus/2020/05/19/impact-of-covid-19-on-micro-small-and-mediu m-businesses-in-uganda

Lerbinger, O. (2012). The Crisis Manager: Facing Disasters, Conflicts and Failures (2nd ed.). New York: Routledge.

McConnell, A. (2011). Success? Failure? Something in-between? A Framework for Evaluating CrisisManagement. Policy and Society, 30, 63-76.

Oladeinde, O. (2020). Nigeria: Coronavirus - Nigeria Cuts Oil Benchmark to \$30, Slashes Capital Budget By 20\% Premium Times Abuja.

Oparanma, A. O., \& Wechie, I. (2014). Crisis management processes to ensure effective and continuous performance.

Ozili, P., \& Arun, T. (2020). Spillover of COVID 19, impact on the global Economy.10.2139\ssrn.3562570.

Robbins, S., Judge, T., \& Campbell, T. (2010). Organizational Behaviour. Harlow: Pearson.

Simola, S. (2013). Teaching Corporate Crisis Management through business ethics education. European Journal of Training and Development, 38(5). https://doi.org/10.1108/EJTD-05-2013-0055

Taneja, S., Pryor, M., Sewell, S., \& Recuero, A. (2014). Strategic Crisis Management: A Basis for Renewal and Crisis Prevention. Journal of Management Policy \& Practice, 15(1), 78-85.

Tashanova, D., Sekerbay, A., \& Chen, D., Luo, Y., Zhao, S. \& Zhang, Q. (2020). Investment Opportunities and Strategies in an Era of Coronavirus Pandemic. Retrieved from https://ssrn.com/abstract=3567445 or http://dx.doi.org/10.2139/ssrn.3567445

Topper, B., \& Lagadec, P. (2013). Fractal crises - a new path for crisis theory and management. Journal of Contingencies \& Crisis Management, 21(1). https://doi.org/10.1111/1468-5973.12008

U.N. (2020). SDGs.: Sustainable Development Knowledge Platform. Retrieved from https://Sustainabledevelopment.Un.Org/Topics/Sustainabledevelopmentgoals

Wobodo, C., \& Oparanma, A. (2019). Crisis management and corporate resilience of multinational oil and gas companies in Rivers State: A theoretical perspective. American Journal of Humanities and Social Sciences Research, 7-14.

Wobodo, C., Asawo, S., \& Asawo, S. (2018). Knowledge Sharing and Employee Resilience in Tertiary Institutions in Port Harcourt.

Wong, P. (2014). Viktor Frankl's Meaning-Seeking Model and Positive Psychology. https://doi.org/10.1007/978-1-4939-0308-5_10

World Health Organization (WHO). (2020). Director-General's opening remarks at the media briefing on COVID-19-11 th March. World Health Organization. Retrieved from http://www.who.org

Worldometer. (2021). Coronavirus Update (Live): 123,877,740 Cases and 2,727,921 Deaths from COVID-19 Virus Pandemic - $\quad$ Worldometer. Worldometer. Retrieved from https://www.worldometers.info/coronavirus/?utm_campaign=homeAdvegas 1 ?\%22\#countries

\section{Copyrights}

Copyright for this article is retained by the author(s), with first publication rights granted to the journal.

This is an open-access article distributed under the terms and conditions of the Creative Commons Attribution license (http://creativecommons.org/licenses/by/4.0/). 